\title{
Ground-based PTR-MS measurements of reactive organic compounds during the MINOS campaign in Crete, July-August 2001
}

\author{
G. Salisbury ${ }^{1}$, J. Williams ${ }^{1}$, R. Holzinger ${ }^{1}$, V. Gros ${ }^{1}$, N. Mihalopoulos ${ }^{2}$, M. Vrekoussis ${ }^{2}$, R. Sarda-Estève ${ }^{3}$, \\ H. Berresheim ${ }^{4}$, R. von Kuhlmann ${ }^{1}$, M. Lawrence ${ }^{1}$, and J. Lelieveld ${ }^{1}$ \\ ${ }^{1}$ Department of Air Chemistry, Max Planck Institute for Chemistry, Mainz, Germany \\ ${ }^{2}$ Department of Chemistry, University of Crete, Heraklion, Crete, Greece \\ ${ }^{3}$ Laboratoire des Sciences du Climat et de l'Environnement, Gif-sur-Yvette, France \\ ${ }^{4}$ German Weather Service, Hohenpeissenburg, Germany
}

Received: 16 December 2002 - Published in Atmos. Chem. Phys. Discuss.: 20 February 2003

Revised: 27 June 2003 - Accepted: 1 July 2003 - Published: 3 July 2003

\begin{abstract}
This study presents measurements of acetonitrile, benzene, toluene, methanol and acetone made using the proton-transfer-reaction mass spectrometry (PTR-MS) technique at the Finokalia ground station in Crete during the Mediterranean INtensive Oxidant Study (MINOS) in JulyAugust 2001. Three periods during the campaign with broadly consistent back trajectories are examined in detail. In the first, air was advected from Eastern Europe without significant biomass burning influence (mean acetonitrile mixing ratio $154 \mathrm{pmol} / \mathrm{mol}$ ). In the second period, the sampled air masses originated in Western Europe, and were advected approximately east-south-east, before turning southwest over the Black Sea and north-western Turkey. The third well-defined period included air masses advected from Eastern Europe passing east and south of/over the Sea of Azov, and showed significant influence by biomass burning (mean acetonitrile mixing ratio $436 \mathrm{pmol} / \mathrm{mol}$ ), confirmed by satellite pictures. The mean toluene:benzene ratios observed in the three campaign periods described were $0.35,0.37$ and 0.22 , respectively; the use of this quantity to determine air mass age is discussed. Methanol and acetone were generally well-correlated both with each other and with carbon monoxide throughout the campaign. Comparison of the acetone and methanol measurements with the MATCH-MPIC model showed that the model underestimated both species by a factor of 4 , on average. The correlations between acetone, methanol and $\mathrm{CO}$ implied that the relatively high levels of methanol observed during MINOS were largely due to direct biogenic emissions, and also that biogenic sources of acetone were highly significant during MINOS $(\sim 35 \%)$. This in turn suggests that the model deficit in both species may be due, at least in part, to missing biogenic emissions.
\end{abstract}

Correspondence to: G. Salisbury

(gavins@mpch-mainz.mpg.de)

\section{Introduction}

Measurements of organic compounds, particularly oxygenated species, in the atmosphere of the Eastern Mediterranean away from the large urban conurbations, are very scarce in the literature. Leaving aside plant emission data, a review of the literature revealed only two extensive data sets, namely the AEROBIC intensive campaign at an elevated forested site in central Greece in 1997 (Harrison et al., 2001; Tsigaridis and Kanakidou, 2002) and a longer-term series of canister measurements carried out at an altitude of ca. $1000 \mathrm{~m}$ in the Peloponnisos region of Greece in 1996 and 1997 (Moschonas and Glavas, 2000). Yet the Mediterranean region is likely to be of considerable importance to the air quality over a much wider region, since in summer relatively stable conditions prevail in the lower troposphere, where air is advected south/south-east from the industrial European nations and is subsequently transported to northern Africa and the Middle East (Mihalopoulos et al., 1997; Sanz and Millán, 1998; Lelieveld et al., 2002). Since the climate of the Mediterranean in summer is characterised by highpressure, cloud-free conditions, high photochemical activity is to be expected, and the atmospheric processing of organic species emitted over continental Europe will be considerable.

The Finokalia measurement station, on the North coast of Crete ca. $70 \mathrm{~km}$ east of Heraklion $\left(35^{\circ} 19^{\prime} \mathrm{N}, 25^{\circ} 40^{\prime} \mathrm{E} ; 130 \mathrm{~m}\right.$ above sea level; Fig. 1), is ideally placed to examine the air masses advected from continental Europe in summer. Local pollution is restricted to a few cars per day passing on a minor coastal road ca. $50 \mathrm{~m}$ west of and some $20 \mathrm{~m}$ below the station. Coastal orography shifts the local wind direction from north/north-west to almost due west in summer, and only a slight sea-breeze oscillation in wind direction between day and night is generally observed. Air passing a substantial distance over Crete before arrival at the site is therefore 


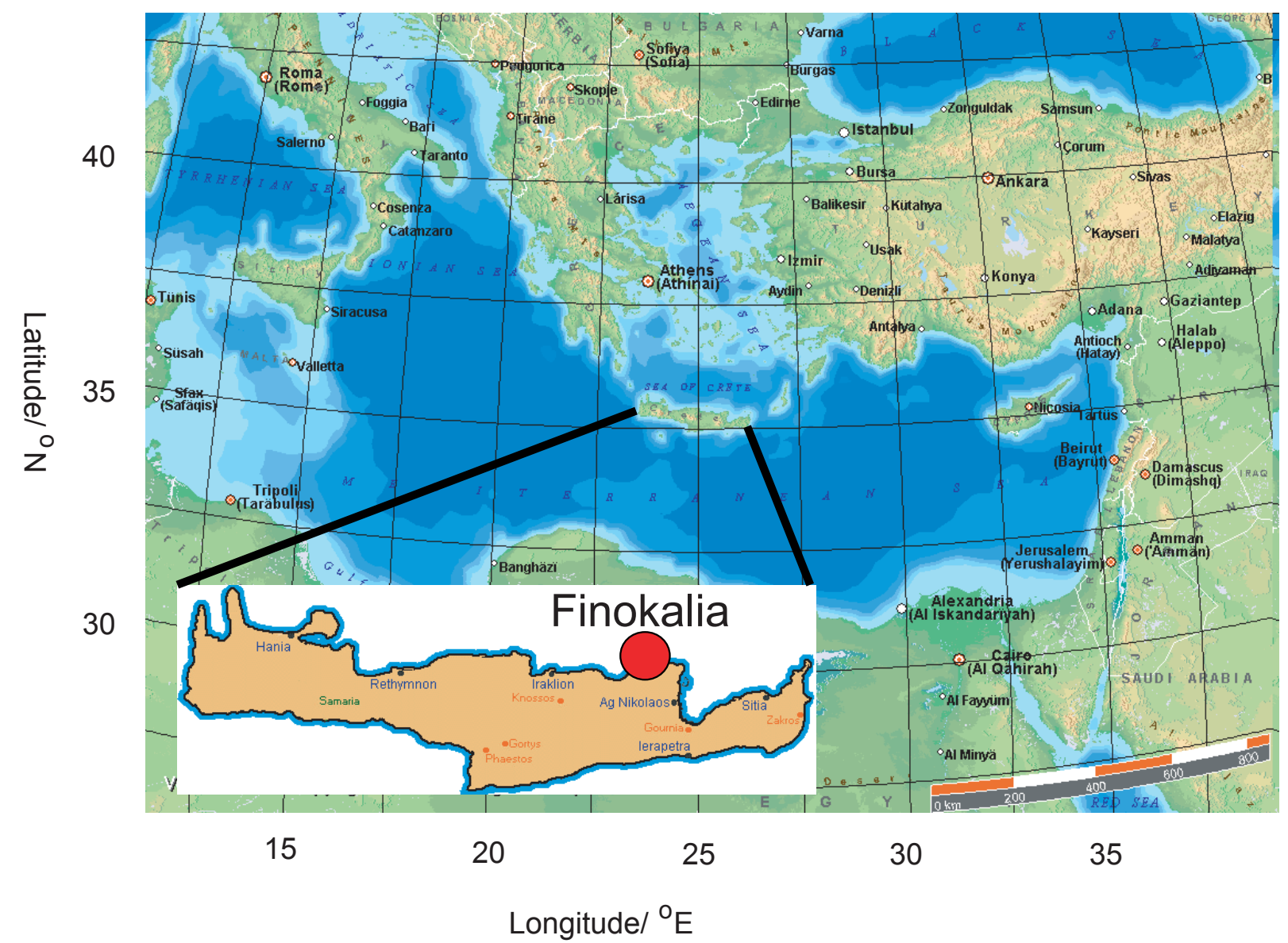

Fig. 1. Location of Finokalia measurement station, site of the ground-based measurements during MINOS, July-August 2001.

rare at Finokalia under these conditions (Mihalopoulos et al., 1997), so that local effects on the atmospheric chemistry are minimal for long periods.

This paper presents measurements of acetonitrile, benzene, toluene, acetone and methanol made using the protontransfer-reaction mass-spectrometry (PTR-MS) technique at Finokalia during the Mediterranean INtensive Oxidants Study (MINOS) in July-August 2001. The only reported source of acetonitrile in the atmosphere is from biomass burning (Lobert et al., 1990; Holzinger et al., 1999); the MINOS PTR-MS acetonitrile data are therefore used to assess the extent of biomass-burning influence on the air sampled during the campaign. In contrast, benzene and toluene are also emitted from fossil-fuel use; the toluene:benzene ratio is used in the present work to assess the time elapsed since the air sampled at Finokalia was last polluted.

Sources and sinks of acetone and methanol in the atmosphere are subject to a high degree of uncertainty, since few atmospheric measurements of these species have been made to date, particularly in the boundary layer. The budget of acetone is of major interest, since this compound is believed to be an important source of $\mathrm{HO}_{\mathrm{x}}$ radicals in the upper troposphere, as well as a reservoir for $\mathrm{NO}_{\mathrm{x}}$ through the for- mation of peroxyacetyl nitrate (PAN) (Singh et al., 1995; Wennberg et al., 1998). The role of methanol in the atmosphere is unclear; a recent study suggests that a substantial reservoir of this species may exist in the oceans (Galbally and Kirstine, 2002). On a global scale, biogenic emissions of both species are known to be substantial; for example, Kirstine et al. (1998) found that acetone formed up to $23 \%$ and methanol up to $15 \%$ of the total carbon emissions from grass and clover in pastureland in Victoria, Australia. For acetone, Jacob et al. (2002) estimated that, in percentage contribution terms, the global annual emissions from primary anthropogenic sources (solvent use and motor vehicle emissions) are of the order of $1 \%$, from primary biogenic sources $35 \%$, from secondary production in the air from propane oxidation $22 \%$, and from biomass burning $5 \%$. The total global source strength of acetone was estimated to be ca. $95 \mathrm{Tg} \mathrm{yr}^{-1}$, appreciably more than previously concluded by Singh et al. (2000) (56 $\left.\mathrm{Tg} \mathrm{yr}^{-1}\right)$. Jacob et al. (2002) also proposed a significant global oceanic source for acetone $\left(27 \mathrm{Tg} \mathrm{yr}^{-1}\right)$. On a regional scale, however, a stronger contribution to acetone production from photochemical reactions of anthropogenic emissions might be expected than these figures suggest. 
The global budget of methanol is even more uncertain. Singh et al. (2000) estimated a combined source strength for methanol of the order of $122 \mathrm{Tg} \mathrm{yr}^{-1}$ (range 75$\left.210 \mathrm{Tg} \mathrm{yr}^{-1}\right)$, a total far exceeding the known sinks (40-

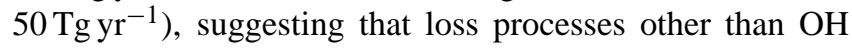
reaction and surface deposition must be important in the atmospheric budget of this compound. In percentage contribution terms, the global annual emissions of methanol from primary anthropogenic sources were estimated to be ca. $2 \%$ (largely from evaporation during solvent use), from primary biogenic sources $61 \%$, from methane oxidation $15 \%$, and from biomass burning 5\%, with the rest coming from decay of plant matter and a possible oceanic source (Singh et al., 2000). Biogenic production of methanol is associated with plant growth, as it is a by-product of pectin hardening around cellulose (see Galbally and Kirstine, 2002). A more recent review of the global methanol budget by Heikes et al. (2002) suggested even greater uncertainty, with a total source strength in the range $90-480 \mathrm{Tg} \mathrm{yr}^{-1}$. In this paper, the sources of acetone and methanol are examined in the light of results from the 3D global chemistry-meteorology model MATCH-MPIC (Model of Atmospheric Transport and Chemistry - Max Planck Institute for Chemistry version). Although the resolution of this model is necessarily coarse, the general lack of measurements of reactive organic species in the Eastern Mediterranean means that the MINOS campaign represented a unique opportunity to test the performance of a global atmospheric chemistry model in a relatively unexplored region, in atmospheric chemistry terms. Of particular interest is whether the GEIA organic emissions scheme used in the MATCH-MPIC model is realistic (see also Gros et al., 2003).

\section{Experimental}

\subsection{The PTR-MS technique}

The PTR-MS technique has been described in detail previously (Hansel et al., 1995; Lindinger et al., 1998); only a brief description will therefore be given here. The principle of the instrument is the reaction of trace organic species in ambient air with $\mathrm{H}_{3} \mathrm{O}^{+}$ions, generated from the hollowcathode discharge of water vapour, to give the protonated organic species $\left(\mathrm{RH}^{+}\right)$. Under typical operating conditions, only a small proportion of the $\mathrm{H}_{3} \mathrm{O}^{+}$ions reacts with the trace species, so that the concentration of the product ions may be calculated from Eq. (1):

$\left(\mathrm{R}_{\mathrm{i}} \mathrm{H}^{+}\right)=\left(\mathrm{H}_{3} \mathrm{O}^{+}\right)_{0}\left(1-\mathrm{e}^{-k_{\mathrm{i}}\left(\mathrm{R}_{\mathrm{i}}\right) t}\right) \approx\left(\mathrm{H}_{3} \mathrm{O}^{+}\right)_{0}\left(\mathrm{R}_{\mathrm{i}}\right) k_{\mathrm{i}} t$,

where $k_{\mathrm{i}}$ is the reaction rate coefficient for the proton transfer reaction from $\mathrm{H}_{3} \mathrm{O}^{+}$to the species $\mathrm{R}_{\mathrm{i}}$, and $t$ is the transit time for the $\mathrm{H}_{3} \mathrm{O}^{+}$ions in the drift tube assembly where the proton transfer reactions occur; the drift tube is held at a pressure of ca. 2 mbar. Only organic species with a proton affinity greater than that of water can be detected. The primary
$\left(\mathrm{H}_{3} \mathrm{O}^{+}\right)$and product ions are detected using a quadrupole mass spectrometer fitted with a secondary electron multiplier detector array.

During the MINOS campaign, over 40 masses were continuously monitored using the PTR-MS instrument; the vast majority of these showed no significant signal except during a few biomass burning events seen on 15 and 17 August (see Sect. 3). The five protonated masses which could be observed and confidently identified (cf. Holzinger et al., 2001a, 2001b, 2003; Warneke et al., 2001; Williams et al., 2001) were as follows: 33 (methanol); 42 (acetonitrile); 59 (acetone); 79 (benzene) and 93 (toluene). The precision of individual measurements was estimated based on the detection limit for each species, calculated from the standard deviation of the background signal at each mass when no organic species were present, using a signal:noise ratio of $2: 1$. For 10 -min average measurements (4 measurement points), the resulting precision values were calculated to be less than $10 \%$ for methanol, acetonitrile, and acetone, $21 \%$ for benzene, and $31 \%$ for toluene, based on typical measured mixing ratios during MINOS of 4, 0.3, 3, 0.2 and $0.06 \mathrm{nmol} / \mathrm{mol}$, respectively. The accuracy of the measurements was largely limited by the accuracy of the rate coefficients, $k_{\mathrm{i}}$. In order to optimise the rate coefficients used for the particular conditions of our instrument, empirical calibration factors were derived for each species using a standard calibration gas mixture diluted to cover a range of mixing ratios, from a few nmol $/ \mathrm{mol}$ to about $1 \mu \mathrm{mol} / \mathrm{mol}$. As the standard was rated to an accuracy of 5\%, the accuracy of the PTR-MS meaurements was estimated to be better than $10 \%$.

\subsection{Measurement site, instrument deployment and support- ing measurements}

The PTR-MS instrument, together with a GC system for the measurement of peroxy acetyl nitrate (PAN; see Lange et al., 2003) and a 2D-GC instrument for the measurement of C7-C14 organic compounds (Xu et al., 2003a, b) were deployed in a measurement container situated ca. $50 \mathrm{~m}$ west of and some $20 \mathrm{~m}$ below the permanent Finokalia station, in a bend of the minor coastal road mentioned in the Introduction. All three instruments sampled from a common $1 / 2$ " Teflon line leading to an inlet situated some $3 \mathrm{~m}$ above the roof of the container and supported on a mast. Canister measurements of light VOCs were also made at $6 \mathrm{~h}$ intervals throughout the campaign, and at much shorter intervals on several days (see Gros et al., 2003 for details.) Neighbouring containers housed instruments for aerosol/particle measurements (Jülich Research Centre/Mainz University; see Schneider et al., 2003) and $\mathrm{OH}$ and $\mathrm{H}_{2} \mathrm{SO}_{4}$ measurements (German Weather Service; see Berresheim et al., 2003). A range of other measurements were made at the Finokalia station during the campaign period, including standard meteorological parameters, radon and thoron, DMS, $\mathrm{NO}, \mathrm{NO}_{2}$, $\mathrm{NO}_{\mathrm{y}}$, black carbon and $\mathrm{O}_{3}$, all carried out by the University 

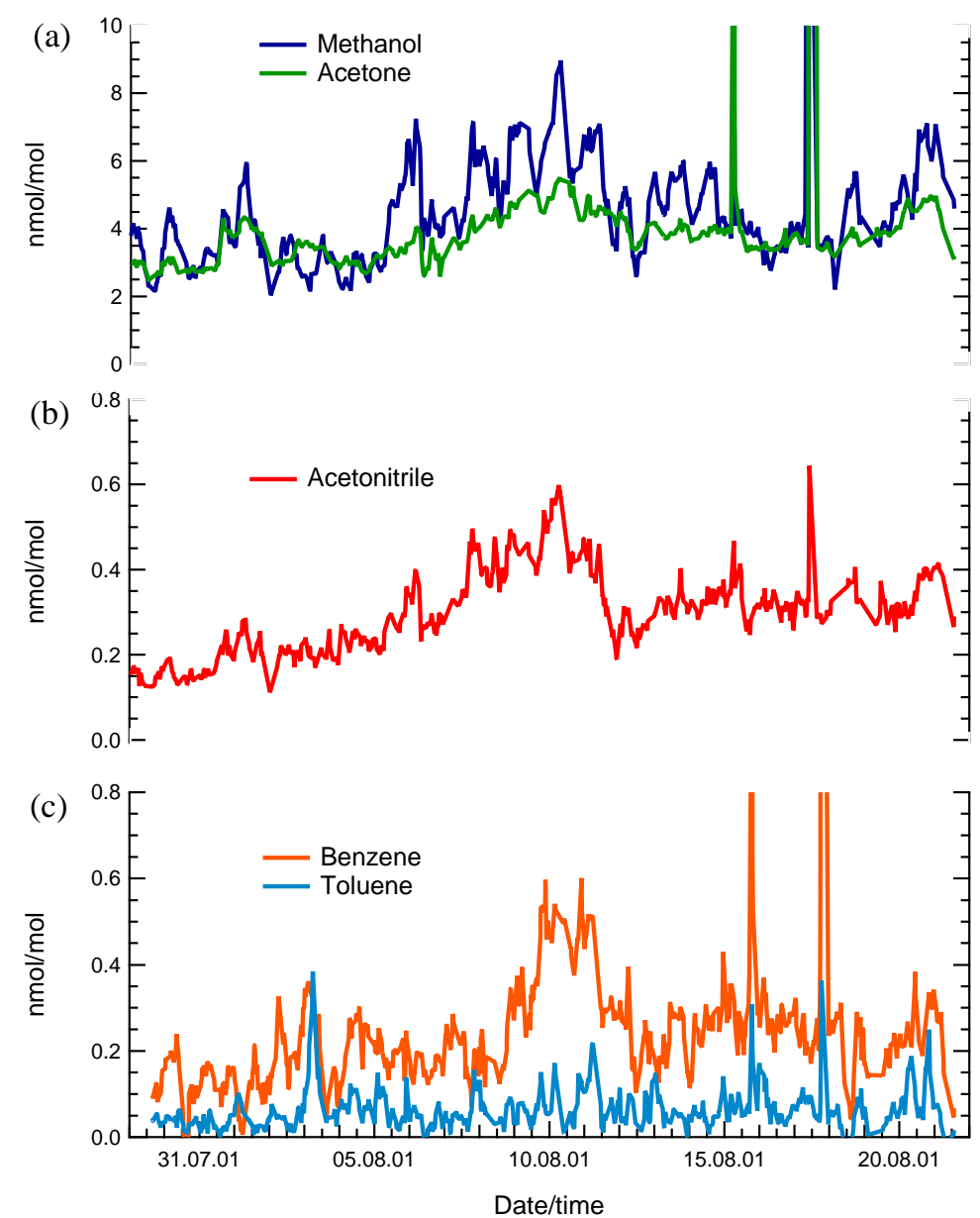

Fig. 2. MINOS PTR-MS time-series of measurements.

of Crete, Heraklion, and CO, carried out by the National Centre for Scientific Research (CNRS), Paris, France.

\section{Results}

\subsection{Back trajectories and air-mass classification}

The full time series of the PTR-MS measurements of methanol, acetone, acetonitrile, benzene and toluene at Finokalia during MINOS are shown in Fig. 2. The data points used in Fig. 2 are 10-min averages with a 5-point running average applied, in order to show more clearly the trends observed during the campaign. Five-day back-trajectory calculations were made for the entire MINOS campaign period at six-hourly intervals for a pressure of 950 mbar using data provided by the European Centre for Medium-Range Weather Forecasting, Reading, UK, via the British Atmospheric Data Centre, Oxford, UK. Based on both the trajectory results and chemical tracers measured at Finokalia, in particular $\mathrm{CO}$, black carbon and acetonitrile, the campaign as a whole was split into four distinct periods for the purposes of further data analysis, as indicated in Fig. 3. Representative trajectories for Periods 1-3 are shown in Fig. 4, which shows that the air throughout all three periods arrived at Finokalia from the north, having passed over the Aegean Sea.

\subsubsection{Period 1 (29 July-2 August) - Air advected from Eastern Europe in the boundary layer}

In Period 1 (Fig. 4a), air originating in Eastern Europe was observed in Crete, although the position of the air mass five days prior to arrival at Finokalia shifted eastwards in the course of this period. The colour-scale for Fig. 4 a (red=low, blue=high throughout) shows that the trajectory heights remained low $(<1200 \mathrm{~m})$ throughout Period 1 . The lowest mixing ratios of acetonitrile were observed at this time (mean $154 \mathrm{pmol} / \mathrm{mol}$; see Table 1). Since acetonitrile has no significant source other than biomass burning (Lobert et al., 1990; Holzinger et al., 1999), it may be inferred that biomassburning influence on the measurements was at its minimum during this part of the campaign. 


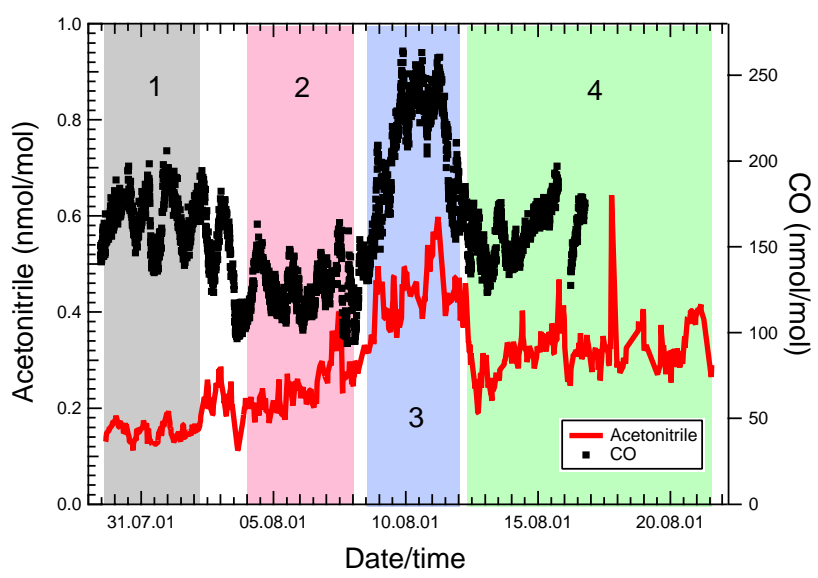

Fig. 3. The time periods defined for data analysis during MINOS.

Table 1. Selected means for Periods $1-3$

\begin{tabular}{|c|c|c|c|}
\hline Species $^{a}$ & Period 1 & Period 2 & Period 3 \\
\hline Methanol & $\begin{array}{l}3.34 \\
(0.61)\end{array}$ & $\begin{array}{l}3.64 \\
(1.25)\end{array}$ & $\begin{array}{l}6.13 \\
(1.20)\end{array}$ \\
\hline Acetone & $\begin{array}{l}2.87 \\
(0.19)\end{array}$ & $\begin{array}{l}3.23 \\
(0.34)\end{array}$ & $\begin{array}{l}4.53 \\
(0.54)\end{array}$ \\
\hline Acetonitrile & $\begin{array}{l}0.154 \\
(0.024)\end{array}$ & $\begin{array}{l}0.245 \\
(0.063)\end{array}$ & $\begin{array}{l}0.436 \\
(0.082)\end{array}$ \\
\hline Benzene & $\begin{array}{l}0.129 \\
(0.068)\end{array}$ & $\begin{array}{l}0.197 \\
(0.079)\end{array}$ & $\begin{array}{l}0.376 \\
(0.134)\end{array}$ \\
\hline Toluene & $\begin{array}{l}0.038 \\
(0.024)\end{array}$ & $\begin{array}{l}0.061 \\
(0.054)\end{array}$ & $\begin{array}{l}0.080 \\
(0.059)\end{array}$ \\
\hline $\mathrm{CO}$ & $\begin{array}{l}166.7 \\
(14.5)\end{array}$ & $\begin{array}{l}125.6 \\
(13.5)\end{array}$ & $\begin{array}{l}209.1 \\
(33.9)\end{array}$ \\
\hline Black carbon $^{b}$ & $\begin{array}{l}749.4 \\
(305.5)\end{array}$ & $\begin{array}{l}872.5 \\
(211.4)\end{array}$ & $\begin{array}{l}2246.6 \\
(586.9)\end{array}$ \\
\hline $\operatorname{Radon}^{c}$ & $\begin{array}{l}1.80 \\
(0.21)\end{array}$ & $\begin{array}{l}1.08 \\
(0.19)\end{array}$ & $\begin{array}{l}1.95 \\
(0.45)\end{array}$ \\
\hline Ozone & $\begin{array}{l}62.1 \\
(6.7)\end{array}$ & $\begin{array}{l}55.6 \\
(6.7)\end{array}$ & $\begin{array}{l}66.4 \\
(2.6)\end{array}$ \\
\hline
\end{tabular}

a All species in nmol/mol except where indicated; standard deviations are in parentheses.

$b \mathrm{ngC} \mathrm{m}^{-3}$

${ }^{c} \mathrm{mBq} \mathrm{m}^{-3}$

\subsubsection{Period 2 (4-7 August) - Western European free tro- pospheric air}

During Period 2 (Fig. 4b), the air arriving at Finokalia originated above the boundary layer in Western Europe, and was advected approximately east-south-east, before descending and turning south-west over the Black Sea and northwestern Turkey. "Non-biomass-burning" anthropogenic influence was at its minimum in this part of the campaign, with mean mixing ratios of carbon monoxide and ozone, for example, of 126 and $56 \mathrm{nmol} / \mathrm{mol}$, respectively.
3.1.3 Period 3 (8-12 August) - Eastern European air heavily influenced by biomass burning

In Period 3 (Fig. 4c), air masses were once again advected from Eastern Europe, but now passed consistently east and south of/over the Sea of Azov; the trajectory height 5 days before Finokalia varied between nearly $3000 \mathrm{~m}$ at the start of Period 3 and less than $900 \mathrm{~m}$ at its end. A notable peak in acetonitrile, $\mathrm{CO}$ and black carbon of long duration occurred during this period, associated with a prolonged biomassburning event. The average acetonitrile mixing ratio during this period was $436 \mathrm{pmol} / \mathrm{mol}$, and carbon monoxide was also considerably higher than earlier in the campaign (Periods 1 and 3 mean mixing ratios 167 and $209 \mathrm{nmol} / \mathrm{mol}$, respectively; see Table 1). Evidence for a large number of fires around the Sea of Azov at this time is provided by the MODIS satellite pictures available from NASA at http://visibleearth.nasa.gov/cgi-bin/viewrecord?9323.

\subsubsection{Period 4 (12-21 August) - Mixed trajectory origins; biomass-burning influence}

The pattern of trajectories for the remaining part of the campaign was far less consistent, being a mixture of those patterns observed in Periods 1-3, although biomass-burning influence remained high until the end of the campaign (see the acetonitrile trace in Fig. 2). The campaign maximum mixing ratios of both acetone and methanol were observed in two short events during Period 4, on 15 and 17 August. Acetonitrile also exhibited pronounced peaks at these times (Fig. 2b), demonstrating that these periods were associated with short, recent biomass-burning events. Peaks of benzene and toluene, as well as most other masses monitored by the PTR-MS instrument during MINOS, were observed at the same time (Fig. 2c). These short events are discussed further in Sect. 4. Otherwise, however, owing to the difficulties in characterising the air masses in Period 4, further analyses in this paper concentrate solely on Periods 1-3.

\subsection{Comparison of Periods 1, 2 and 3}

\subsubsection{Biomass-burning signature}

Periods 1 and 3 provide an interesting contrast between air masses essentially free of direct biomass-burning influence (Period 1; mean acetonitrile mixing ratio $154 \mathrm{pmol} / \mathrm{mol}$ ) and air masses strongly influenced by biomass burning (Period 3; mean acetonitrile mixing ratio $436 \mathrm{pmol} / \mathrm{mol}$ ). Figure 5 shows the time series of the acetonitrile: $\mathrm{CO}$ ratio throughout the campaign, where both increased values and increased variability in the measurements after Period 1 are clearly discernible. The frequency distributions for the same ratio in Period 1 only and for all data later in the campaign (not shown) were also significantly different, with a single maximum at 0.0009 for Period 1 and a single maximum at 0.0020 for the rest of the campaign. It is also of interest to note 

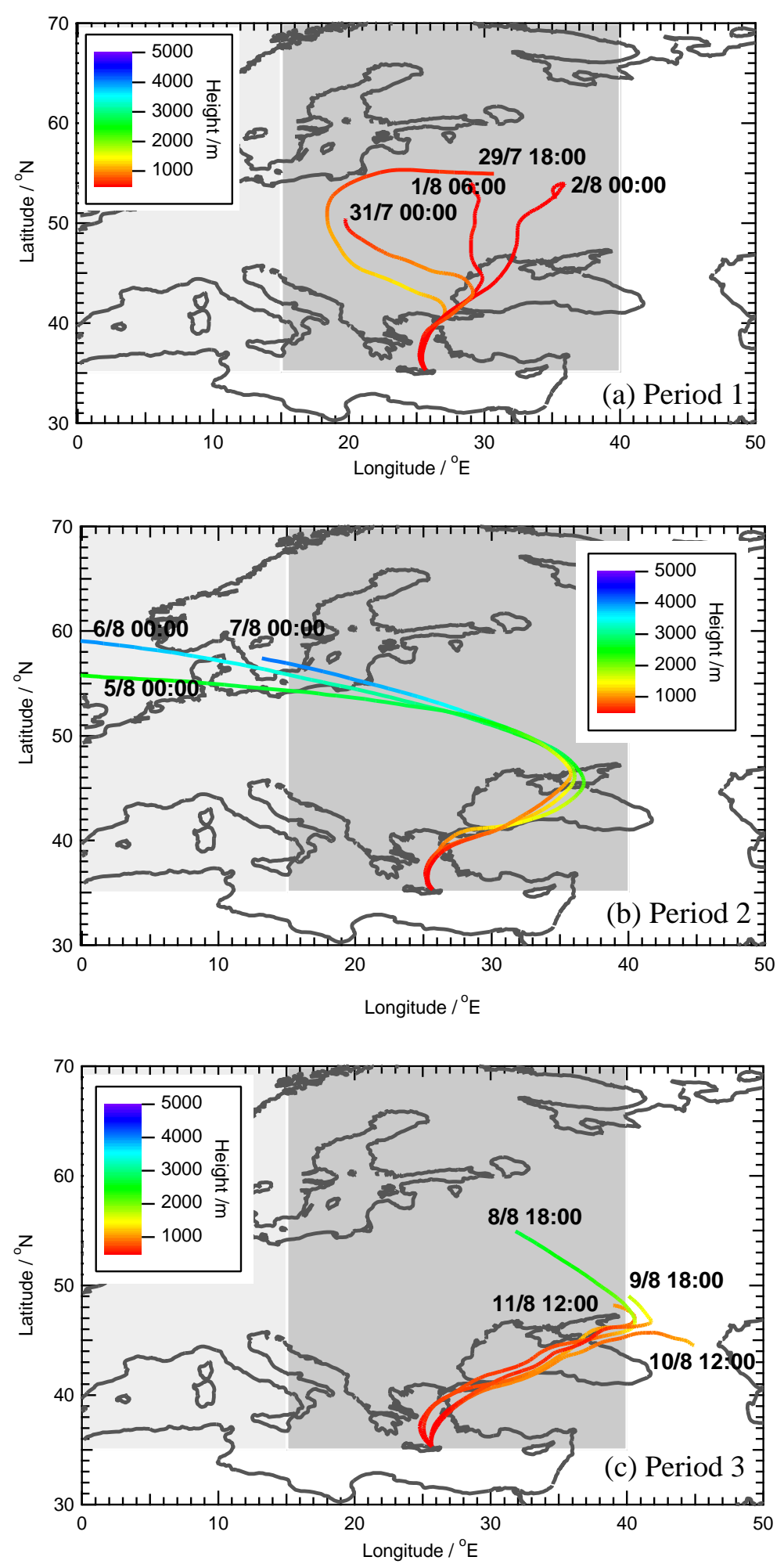

Fig. 4. Five-day back trajectories calculated from Finokalia during the MINOS campaign (950 HPa) using ECMWF data (courtesy of the British Atmospheric Data Centre, UK). Times marked are arrival times at Finokalia (UT). The shaded areas represent the Western European (light grey; $35-70^{\circ} \mathrm{N}, 10^{\circ} \mathrm{W}-15^{\circ} \mathrm{E}$ ) and Eastern European (dark grey; $35-75^{\circ} \mathrm{N}, 15^{\circ} \mathrm{E}-40^{\circ} \mathrm{E}$ ) source regions used in the MATCH-MPIC model (see Sect. 3.3). 


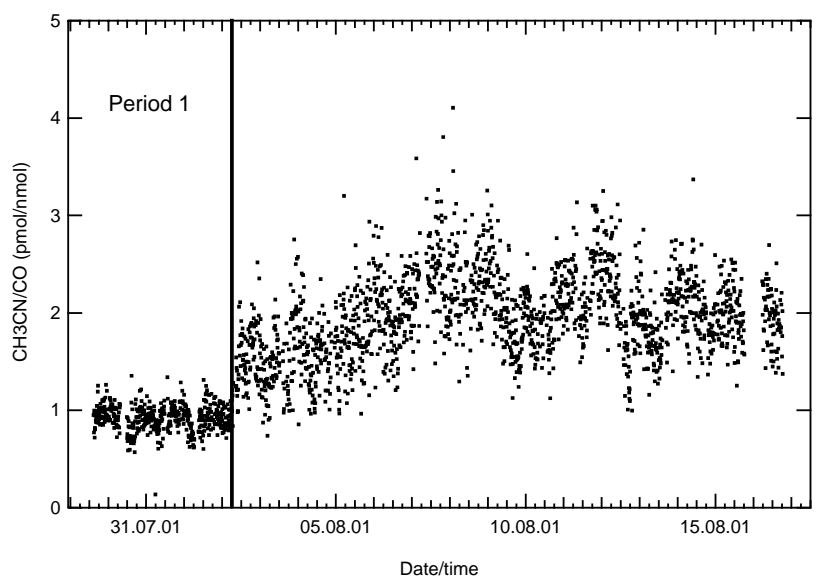

Fig. 5. The acetonitrile:CO ratio during MINOS. Note that for clarity the units here are $\mathrm{pmol} / \mathrm{nmol}$, as opposed to $\mathrm{nmol} / \mathrm{nmol}$ used in the text.

Table 2. Mean values of selected tracer ratios during MINOS

\begin{tabular}{llll}
\hline Ratio $^{a}$ & Period 1 & Period 2 & Period 3 \\
\hline Toluene:benzene & 0.35 & 0.37 & 0.22 \\
& $(0.55)$ & $(0.72)$ & $(0.17)$ \\
Acetone:methanol & 0.88 & 0.97 & 0.76 \\
& $(0.13)$ & $(0.28)$ & $(0.11)$ \\
Acetonitrile:CO & 0.0009 & 0.0019 & 0.0021 \\
& $(0.0001)$ & $(0.0005)$ & $(0.0003)$ \\
Methanol:CO & 0.020 & 0.028 & 0.030 \\
& $(0.003)$ & $(0.008)$ & $(0.005)$ \\
Acetone:CO & 0.017 & 0.026 & 0.022 \\
& $(0.001)$ & $(0.002)$ & $(0.002)$ \\
& & &
\end{tabular}

${ }^{a}$ All ratios in $\mathrm{nmol} / \mathrm{nmol}$; standard deviations are in parentheses.

that the mean acetonitrile: $\mathrm{CO}$ ratio in Period 3 (see Table 2), and the mode of the frequency distribution of this quantity (not shown) for the whole campaign after 06:00 on 2 August (0.0021 and 0.0019 , respectively) both match very well the acetonitrile emission factor relative to $\mathrm{CO}$ measured in the laboratory in Mainz 2000 of $0.20 \%$ (Holzinger et al., 2002a). It follows, therefore, that only Period 1 of the campaign may be taken to have been essentially free of direct biomassburning influence; the peak in biomass-burning signal was indeed in Period 3 (see Table 1 and Fig. 3), but some influence of biomass burning was seen throughout the campaign after 2 August. This is clear from the mean quantities given in Table 1: black carbon and benzene, for example, were both higher on average in Period 2 than in Period 1 (mean black carbon concentrations 872.5 and $749.4 \mathrm{ngC} \mathrm{m}^{-3}$; mean benzene mixing ratios 197 and $129 \mathrm{pmol} / \mathrm{mol}$, respectively), despite the relatively low $\mathrm{CO}$ levels during this part of the campaign.

\subsubsection{Tracer ratios}

Table 2 shows that the acetone:methanol ratio averaged 0.9 1.0 in Periods 1 and 2, but was lower (mean < 0.8) in Period 3. Since the atmospheric lifetimes of acetone and methanol for conditions at Finokalia (using the Period 2 mean $\mathrm{OH}$ concentration of $3.6 \times 10^{6}$ molecules $\mathrm{cm}^{-3}$ and measured UV irradiances) were ca. 11 and $3.5 \mathrm{~d}$, respectively, it may be concluded that methanol emission from the biomass burning observed in Period 3 was greater than acetone emission. This qualitative conclusion is supported by laboratory biomass-burning measurements made using a PTR-MS instrument in Mainz in 1997 and 2000, where the mean emission factors, expressed as a percentage of CO emission, were 0.64 and $0.77 \%$ for methanol, and 0.54 and $0.35 \%$ for acetone, respectively (Holzinger et al., 1999; Holzinger et al., 2002a). For comparison, the estimates given by Andreae and Merlet (2001) for the burning of agricultural residues, savannah/grassland and extratropical forest were all ca. $2 \%$ for methanol and $0.5-0.7 \%$ for acetone. The methanol:CO and acetone:CO ratios show the same pattern, so that the mean methanol:CO ratio in Period $3(0.030)$ was $50 \%$ higher than in Period 1 (0.020), whereas the acetone:CO ratio was on average only $29 \%$ higher in Period $3(0.022)$ than in Period 1 (0.017). Looking at the data in a different way, we note that the enhancements in the mixing ratios for $\mathrm{CO}$, acetone and methanol from Period 1 to Period 3 were $42.4,1.66$, and $2.79 \mathrm{ppbv}$, respectively, based on the averages given in Table 1. If we assume that these enhancements were entirely due to biomass burning, we obtain the "biomass-burning" methanol: $\mathrm{CO}$ and acetone: $\mathrm{CO}$ ratios 6.5 and $3.9 \%$, respectively. Clearly these ratios are much higher than the PTR-MS lab measurements and literature values of the emission ratios, and may indicate secondary production of both species in the biomass-burning plume (see for example Mauzerall et al., 1998; Reiner et al., 2001; Jacob et al., 2002), and/or that the observed enhancements were not simply due to biomass burning (see Sect. 4.1).

\subsubsection{Diel cycles}

Figures 2 and 3 show that pronounced diel cycles were observed both in the PTR-MS measurements and in the CO measurements during MINOS. The mean diel cycles for methanol, acetone, acetonitrile, $\mathrm{CO}$, ozone and wind direction are given for Periods 1 and 3 in Fig. 6. The first point to note when considering Fig. 6 is that the averaged cycles shown represent less than four complete days in each case. Nevertheless, without over-interpreting the data, several interesting points can be made from this analysis. First, it may be noted that none of the trace gases were strongly correlated or anti-correlated with changes in local wind direction for either campaign period (bottom panels of Fig. 6), with the possible exception of ozone in Period 3. This supports our assertion that local emissions and orographic features at the 


\section{Period 1}
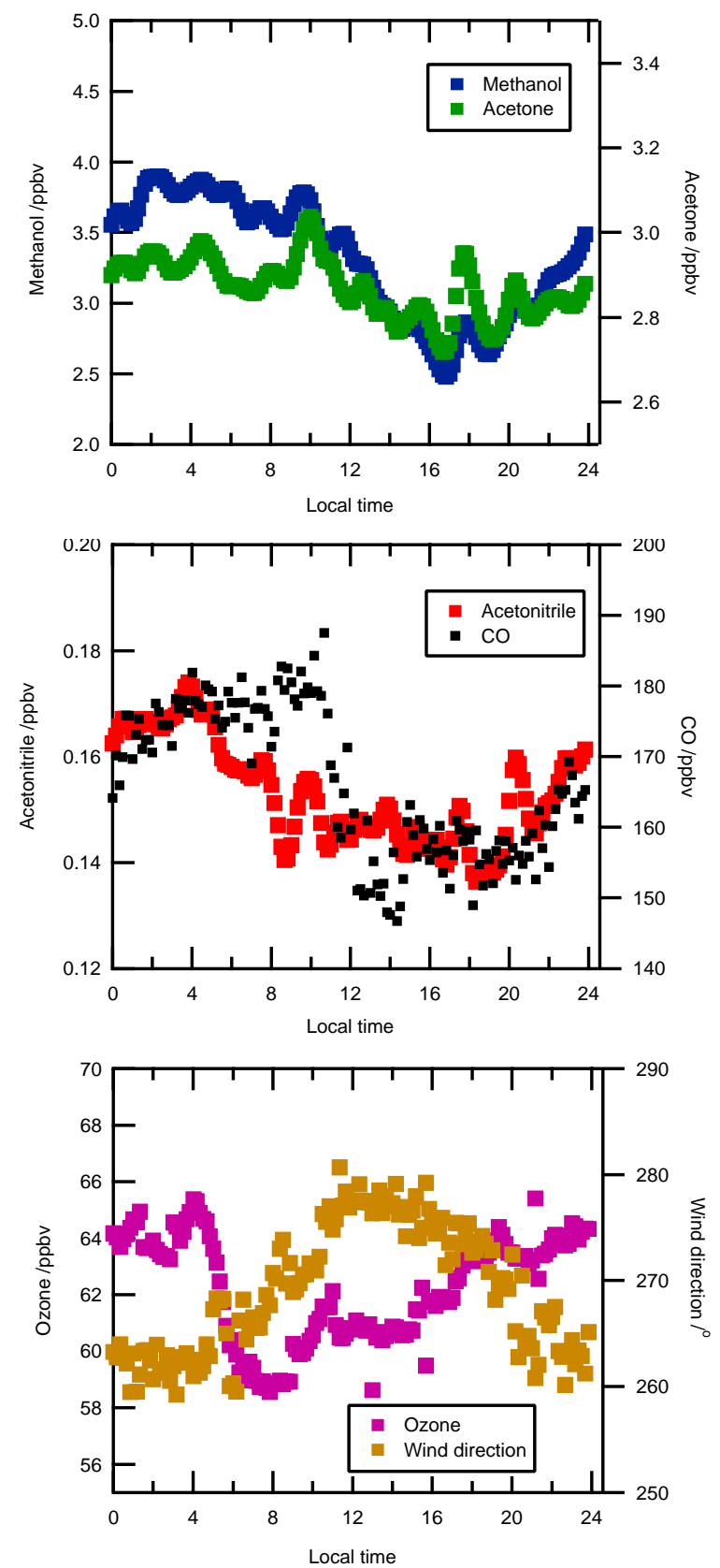

Period 3
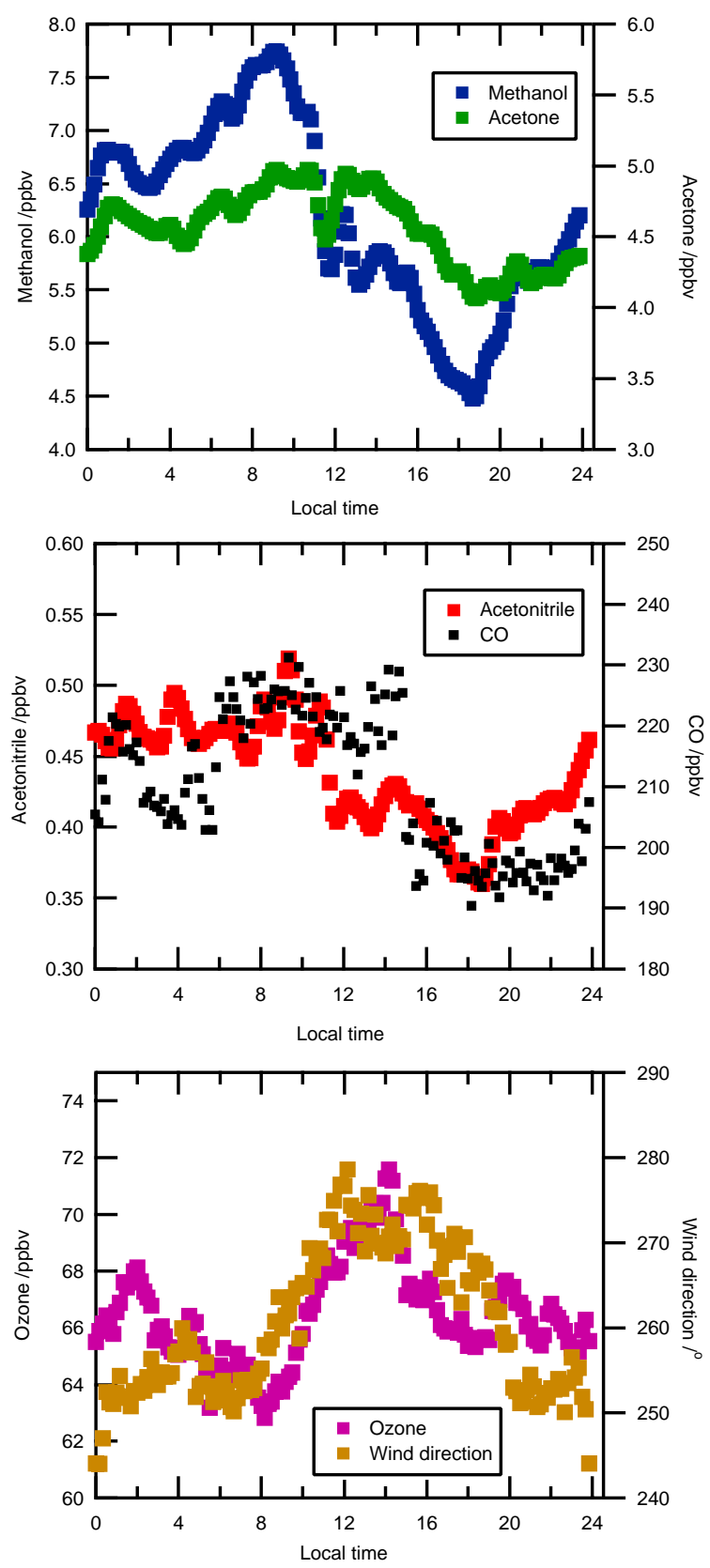

Fig. 6. Mean diel cycles for selected trace gases and wind direction during Periods 1 and 3 of MINOS.

Finokalia site did not affect the PTR-MS measurements to any significant degree. Second, while in Period 3 there was a clear daytime peak of ozone, suggestive of local photochemical ozone production, the ozone diel cycle in Period 1 was more complex, and clearly involved the interplay of chemical and dynamical effects. Since inspection of Fig. 6 shows also that none of the other trace gases correlated strongly with ozone during either period, we can be confident that the other diel cycles observed, in particular for the purposes of the present work those of methanol and acetone, were not simply owing to local photochemistry. To check this conclusion, the trajectories obtained for Period 1 were used to calculate approximate hours of daylight experienced by the air en route to Finokalia from the Turkish coast. Although 
the peaks in ozone were found to correspond approximately to the calculated peaks in the number of daylight hours en route to the measurement site, no correlation, either positive or negative, was observed between either methanol or acetone and the number of daylight hours in this manner. Moreover, in Period 1, general decreases in methanol, acetone and $\mathrm{CO}$ were observed between ca. 08:00 and 18:00 local time, although it must be noted that the acetone diel cycle in Period 1 was much weaker than the other two, and might not be significant. The acetonitrile profile shows that the degree of biomass-burning influence at this time was small and variable, although clearly non-zero. Acetonitrile was not correlated with any other parameter, and was likely controlled by the emission rates from distant sources.

In Period 3, methanol, $\mathrm{CO}$ and acetonitrile all showed clear decreases between ca. 09:00 and 19:00 local time. One possible explanation for these observations is that the increasing radiation-induced turbulence during the daytime mixed less polluted free tropospheric air into the boundary layer. If this were the case, the overlying air must have been rather less influenced by biomass burning, to judge from the acetonitrile diel cycle. The acetone diel cycle does not fit this pattern, however, and it seems clear from Fig. 6 that photochemical production of acetone was also occurring at this time, presumably due to higher levels of photochemical precursors than those observed in Period 1 of the campaign. It may be noted that acetone began to rise at ca. 04:00 local time, i.e. before sunrise and long before ozone started to rise (ca. 08:00), which would indicate that the photochemical acetone production observed was not occurring locally. The combination of diel cycling in the importance of the biomassburning influence (cf. the methanol diel cycle) and regional photochemical production of acetone ensured that the averaged acetone peak did not coincide with those of either ozone or acetonitrile.

The diel cycle of methanol in Period 3 is particularly striking, and since methanol is highly water-soluble, a possible role of the ocean, either through uptake, emission or possibly both, cannot be ruled out. Indeed, the amplitude of the diel variation (defined as 90th percentile-10th percentile/mean mixing ratio) for methanol was much greater in both periods (35 and $41 \%$, respectively) than for acetone ( 8 and $17 \%$, respectively).

In summary, consideration of Fig. 6 provides evidence that the diel cycles observed during MINOS were mainly as a result of advection to the site and/or vertical mixing, with evidence of photochemical production only seen in the cases of ozone (possibly in both periods) and acetone in Period 3.
3.3 Comparison of the acetone and methanol measurements with the MATCH-MPIC model output

\subsubsection{Introduction to the MATCH-MPIC model}

The model runs here were done with the Model of Atmospheric Transport and Chemistry, Max Planck Institute for Chemistry version 3.0 (hereafter MATCH-MPIC), described and evaluated in Rasch et al. (1997), Mahowald et al. (1997a, b), Lawrence et al. (1999), and von Kuhlmann (2001), and references therein. MATCH is an offline model that uses basic meteorological parameters (pressure, temperature, horizontal winds, surface heat fluxes, and surface stresses) from the National Centers for Environmental Prediction (NCEP) aviation forecasts (Caplan and Pan, 2000). The meteorology component of MATCH simulates advective transport, convection, vertical diffusion, cloud fractions, and cloud microphysics (Lawrence et al., 1999). A horizontal resolution of approximately $2.8^{\circ} \times 2.8^{\circ}$ (T42) was used in this study.

The tropospheric chemistry module of MATCH-MPIC is described in detail in Lawrence et al. (1999), von Kuhlmann (2001), and von Kuhlmann et al. (2003a,b) (see also http:// www.mpch-mainz.mpg.de/ $\sim$ kuhlmann). It includes isoprene chemistry based on the Mainz Isoprene Mechanism (Pöschl et al., 2000), as well as representations of ethane, propane, ethene, propene, and n-butane (von Kuhlmann, 2001). Photochemical production of acetone in the model occurs explicitly solely from propane; higher iso-alkanes do not represent a source of acetone, since n-butane chemistry, which is used as a pool for higher alkanes, does not produce acetone. Acetone from oxidation of terpenes is not explicitly included, but is accounted for as part of the total biogenic emissions of $40 \mathrm{Tg} \mathrm{yr}^{-1}$, which are emitted using the distributions and seasonality of terpenes and other hydrocarbons given by Guenther et al. (1995) in equal weights. This figure is likely too low in the light of the review by Jacob et al. (2002), but is nevertheless higher than in earlier modelling studies. Surface sources are included for $\mathrm{NO}_{\mathrm{x}}, \mathrm{CO}$ and non-methane hydrocarbons (NMHCs) from industrial activities, biomass burning, and soils; the model also includes lightning $\mathrm{NO}_{\mathrm{x}}$ and aircraft emissions. Dry deposition and wet scavenging losses are computed based on the modelled meteorological parameters.

\subsubsection{Results}

The model-output CO data interpolated to the position of Finokalia are plotted together with the measurements in Fig. 7a. Also included in Fig. 7a are the Western European and Eastern European (the two highest) source contributions to the modelled total $\mathrm{CO}$ mixing ratios. Figure $7 \mathrm{a}$ shows that Eastern Europe dominated the CO source in the MATCH results, as expected from the trajectory analyses presented previously, and also that the trends and structure in the total modelled CO derived largely from the Eastern European 
(a)

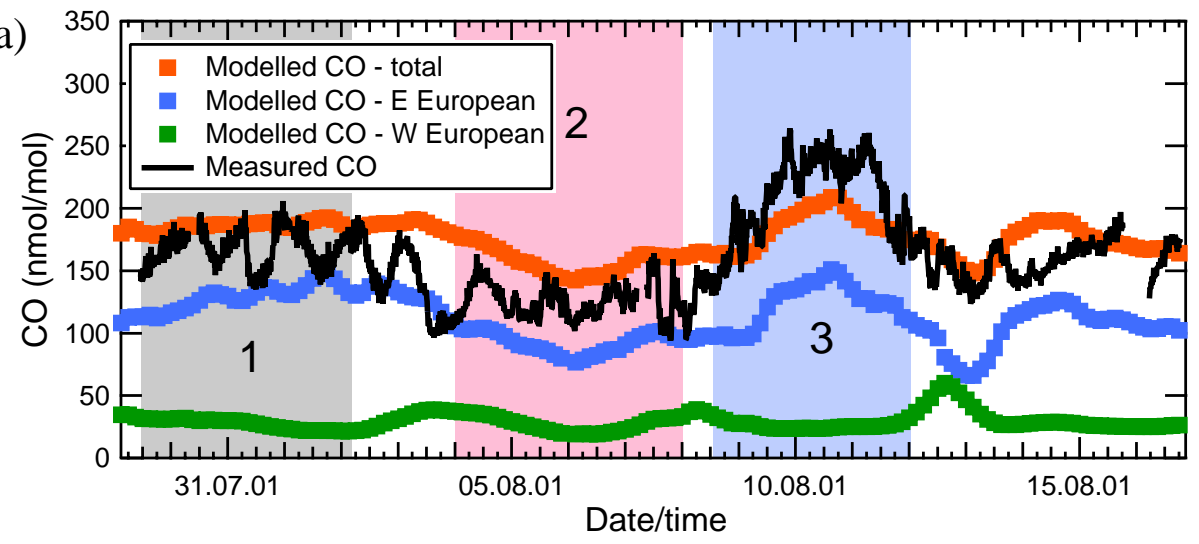

(b)

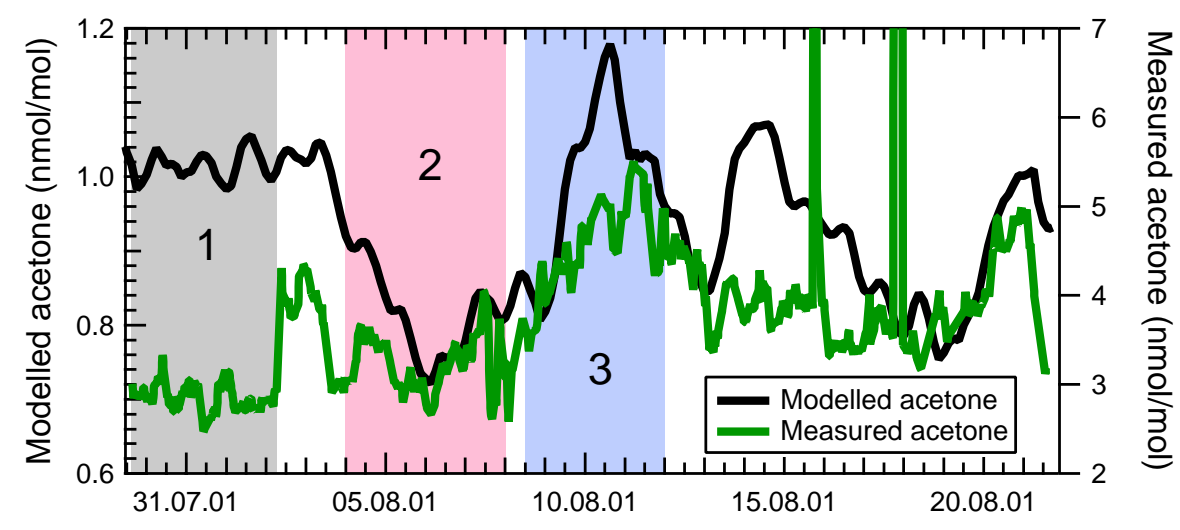

Date/time

(c)
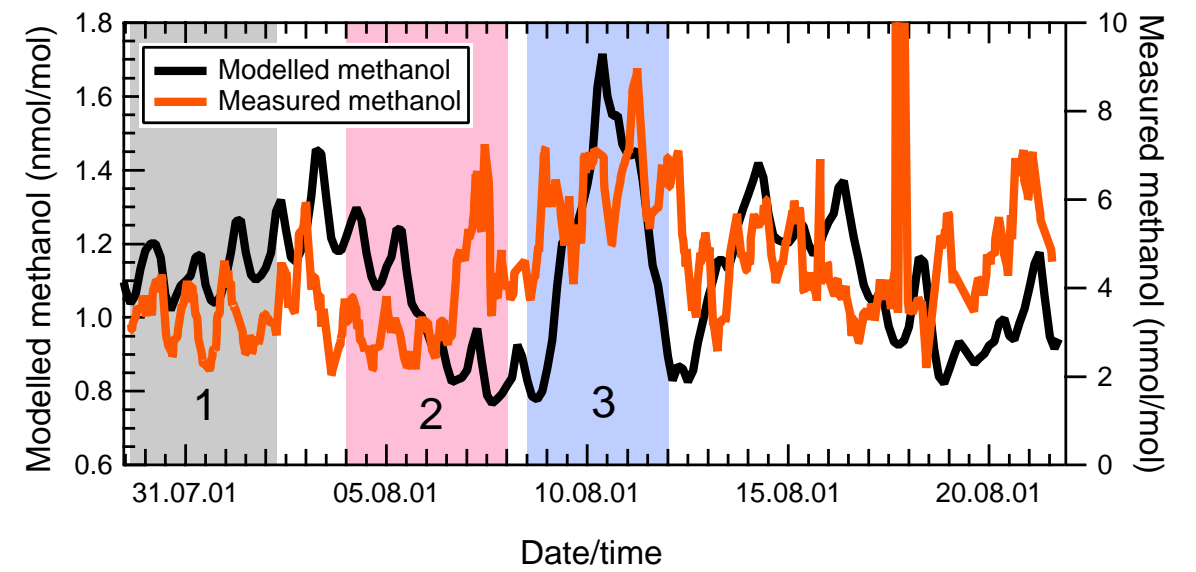

Fig. 7. Comparison of MINOS measurements with MATCH-MPIC model output; Periods 1-3 are marked in each panel.

contribution. The general levels of the measurements, the relatively high levels in Period 1, and the relatively low levels in Period 2 are all captured well by the MATCH-MPIC model. These features represent good evidence that the meteorology in the model was functioning well, and provides a solid basis for comparison of the MATCH acetone and methanol data with the measurements. The model $\mathrm{CO}$ also shows a pronounced peak in Period 3. However, the MATCH model uses a climatological fire scheme, so that this peak (much shorter and sharper than that seen in the measurements) will not represent the actual fires burning at that time.

The model-output acetone and methanol mixing ratios interpolated to the position of Finokalia are plotted together with the PTR-MS measured values in Figs. $7 \mathrm{~b}$ and c, respectively. It is important to note that in each case the 5point smoothed measured data are used (as in Fig. 2), and 
are plotted on a different scale. Figure $7 \mathrm{~b}$ shows that the relatively low levels in Period 2, as well as the peak in Period 3, were both reproduced in the modelled acetone data, although the absolute mixing ratios were considerably lower throughout. On average the acetone measurements were four times higher than the model (model: measurement ratio 0.26; standard deviation 0.05). A similar pattern was evident in the methanol comparison (Fig. 7c), where the highest methanol levels were observed during Period 3 in both model and measurements, but once again the absolute mixing ratios were lower than the measured values by a factor of ca. 4 (mean methanol model:measurement ratio over the whole MINOS period 0.28 ; standard deviation 0.10 ).

As noted in Sect. 3.2.3, diel cycles were evident in the measurements of both species, but particularly marked for methanol (see Figs. 3 and 6). Similar cycles were observed in the model output, albeit not necessarily exactly synchronous, and of smaller amplitude. These results suggest that the model captured rather well at least the chemical behaviour of both species, since the chemical mechanisms of production and loss of acetone and methanol in the atmosphere are quite dissimilar. Acetone is produced in quite high yield from the oxidation of a range of volatile organic compounds, and is photolysed quite rapidly, whereas methanol is produced largely from methane oxidation (see Sect. 4.2) and is not photolysed (Singh et al., 2000; Jacob et al., 2002). The large shortfall in the modelled levels of acetone and methanol seems likely, therefore, to be due to deficiencies in the emissions inventory of methanol and acetone themselves, as well as in acetone's chemical precursors. This conclusion is supported by the comparison of MINOS propane measurements with MATCH output propane data presented by Gros et al. (2003); MATCH was found to underestimate propane (a significant precursor of acetone) by a factor of 1.5-3. This deficiency in propane is, however, not sufficient to explain the shortfall in acetone. Even assuming 100\% yield of acetone from $\mathrm{OH}$-oxidation of propane, the MINOS campaign mean propane mixing ratio of $235 \mathrm{pmol} / \mathrm{mol}$ implies an upper limit to the "missing" acetone of ca. $0.8 \mathrm{nmol} / \mathrm{mol}$, taking into account the different lifetimes of the two species. Since the actual mean acetone deficit over the whole MINOS campaign (excluding the short biomass-burning peaks in Period 4) was $2.9 \mathrm{nmol} / \mathrm{mol}$, we can conclude that a maximum of ca. $30 \%$ of the shortfall in acetone mixing ratios in the MATCH results can be accounted for by deficiencies in propane emissions in the model.

Figure 7 also shows, however, that the model:measurement ratio for both compounds was rather variable over the campaign as a whole, suggesting weaknesses in the distribution of emissions in the model, and that emissions are underestimated to differing extents according to type and source region. In the case of methanol, these observations in turn suggest that the relatively high mixing ratios measured during MINOS arose largely from direct emissions.

\section{Discussion}

4.1 Use of the toluene:benzene ratio as an indicator of air mass age

Table 2 indicates that the toluene:benzene ratio was considerably lower in Period 3 (0.22) than in Periods 1 and 2 (0.35 and 0.37 , respectively); this observation is explicable with reference to the emission ratios of the two species. Anthropogenic emissions typically have a toluene:benzene ratio of $2-3: 1$, whereas the biomass-burning emission ratio is of the order of 1:2 (Merlet and Andreae, 2001).

The use of the toluene:benzene ratio to indicate the time since an air mass last encountered anthropogenic emissions (commonly known as the air mass "age") is based on the differing rates of reaction of the two compounds with the $\mathrm{OH}$ radical, as shown in Eq. (2) (see for example, Roberts et al., 1984; McKenna et al., 1995).

$$
\text { Air mass age } \approx\left\{\ln (\mathrm{X} / \mathrm{Y})_{0}-\ln (\mathrm{X} / \mathrm{Y})_{t}\right\} /\left\{\left(k_{\mathrm{X}}-k_{\mathrm{Y}}\right)^{*}(\mathrm{OH})\right\},
$$

where $\mathrm{X}$ represents toluene, $\mathrm{Y}$ benzene, $t$ represents the time since the compounds were emitted into the atmosphere (at time $t=0), k$ is the rate coefficient for the reaction of each compound with $\mathrm{OH}$, and $(\mathrm{OH})$ represents an integrated $\mathrm{OH}$ concentration over the lifetime of the air mass. The calculation assumes that there is one well-defined source of both compounds, there are no other significant chemical or physical losses of either molecule, and that mixing of the air mass with "background" air has no significant effect on the ratio. In practice, since the lifetime of benzene in the atmosphere is considerably longer than that of toluene, mixing has the effect of artificially reducing the toluene:benzene ratio. Air mass ages calculated by this technique must therefore be considered as upper limits. Other assumptions in the calculation are the toluene:benzene emission ratio and the $\mathrm{OH}$ concentrations assumed. For Periods 1 and 2, the toluene:benzene emission ratio was taken to be ca. 3:1, assuming that measurements of these species in central Athens (Moschonas and Glavas, 1996) are representative of urban centres over the wider source region observed in this study. For Period 3, the last emissions of toluene and benzene were assumed for the purposes of this calculation to be from biomass burning. However, the toluene:benzene emission ratio for the burning of agricultural residues calculated from data presented by Andreae and Merlet (2001) is 0.19 , which is lower than the mean toluene:benzene ratio measured in Period 3 of 0.22 (Table 2), and therefore clearly much too low. Consequently as a starting point for discussion the emission ratio of 0.57 for the "savannah-grassland" vegetation type (Andreae and Merlet, 2001) was used (see below). The 24-h mean $\mathrm{OH}$ concentrations measured at Finokalia during Periods 2 and 3 of MINOS were used in the calculation; since there were no $\mathrm{OH}$ measurements available for Period 1, the Period 2 24-h average concentration of $3.6 \times 10^{6}$ molecules $\mathrm{cm}^{-3}$ was also used in the air mass age calculation for this period. 
The mean air mass ages for Periods 1 and 2 were $35 \mathrm{~h}$ and $34 \mathrm{~h}$, respectively. Examination of the back trajectories for these periods showed that the time since the air sampled at Finokalia left the coast of the mainland varied between 12.5 and $20 \mathrm{~h}$ for Period 1 , and 12 and $29 \mathrm{~h}$ for Period 2. The calculated air mass ages seem reasonable, therefore, and suggest that the air measured at Finokalia during these periods was last polluted in north-western Turkey (Istanbul region; see Figs. 4a and b).

The calculated mean air mass age for Period 3 was just $15 \mathrm{~h}$, even using a biomass-burning toluene:benzene emission ratio of 0.57 rather than 0.19 . However, this result will be too low if the air was also influenced by anthropogenic emissions. Evidence that this was indeed the case is provided by the methyl chloroform data, presented by Gros et al. (2003), since the levels of this tracer were also elevated during part of Period 3. The time since the air sampled at Finokalia during Period 3 left the coast of the mainland varied between 12 and $21.5 \mathrm{~h}$, based on the trajectory analysis. As noted previously, satellite pictures taken at this time confirmed high biomass-burning activity in Eastern Europe north and east of the Black Sea. Clearly, however, the air later sampled at Finokalia then passed over populated areas in Turkey, as in Periods 1 and 2, so that the biomass-burning influence will inevitably have been mixed with additional anthropogenic emissions, as our data show.

Air mass ages were also calculated for the short-duration biomass burning events observed with the PTR-MS instrument on 15 and 17 August (during Period 4; see Fig. 2) using the Period 4 24-h average $\mathrm{OH}$ concentration of $4.9 \times$ $10^{6}$ molecules $\mathrm{cm}^{-3}$. During these short periods, benzene reached up to ca. $1.3 \mathrm{nmol} / \mathrm{mol}$ and toluene was up to a maximum of ca. $0.4 \mathrm{nmol} / \mathrm{mol}$. The air mass ages were calculated to be $10.9 \mathrm{~h}$ for 15 August and $16.6 \mathrm{~h}$ for 17 August. Examination of the trajectories showed that the time since these air masses had left the coast of the mainland was ca. $14.5 \mathrm{~h}$ for 15 August and ca. $20 \mathrm{~h}$ for 17 August. Since, as already noted, these calculated air mass ages are essentially upper limits, these results suggest that the short-duration fires occurred on one or more of the Greek islands, possibly in the Cyclades. Moreover, the sharpness of these peaks itself suggests that the fires were considerably closer to Finokalia than those observed in Period 3.

In summary, the use of the toluene:benzene ratio to calculate air mass age during MINOS has proved broadly consistent with the trajectory information, although clearly the approach is limited both by the emissions ratio assumed - especially where more than one emission source type is present, as here for Period 3 - and the $\mathrm{OH}$ concentrations used. It is by no means clear that the $\mathrm{OH}$ concentrations measured at Finokalia were representative of those in the air on its path from Turkey to the measurement site.

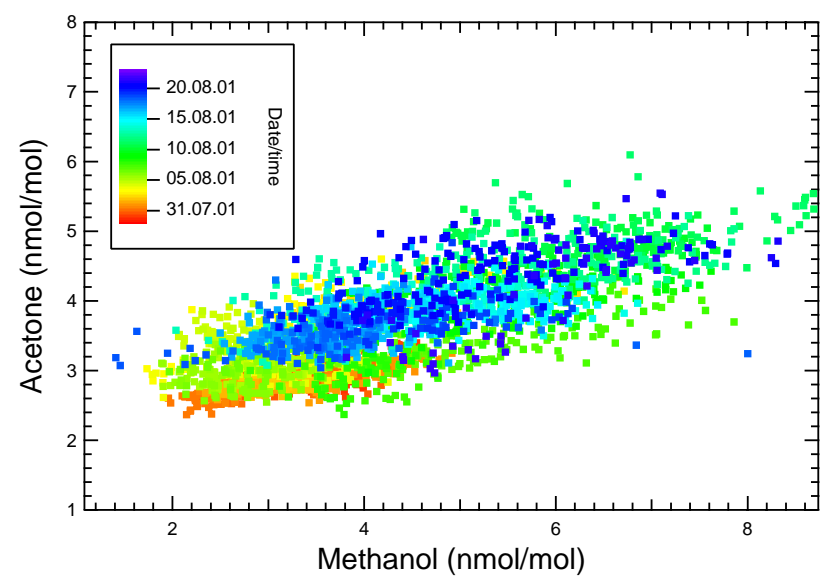

Fig. 8. Correlation between acetone and methanol for the entire MINOS period excluding short biomass-burning events on 15 and 17 August.

\subsection{Sources of acetone and methanol during MINOS}

As discussed in Sect. 3, the MATCH-MPIC model underestimated the measured acetone and methanol measurements by a factor of 3-4 during MINOS. This result suggested that the relatively high mixing ratios of methanol measured during MINOS arose largely from direct emissions, as, unlike acetone, its photochemical production in the atmosphere is slow (see Section 3.2.3 and below). However, as discussed in the Introduction (see Singh et al., 2000; Jacob et al., 2002) the emission inventories of both compounds are rather poorly understood, both qualitatively and quantitatively.

\subsubsection{Relationships between acetone, methanol and CO}

Figure 8 shows that acetone and methanol were, over the campaign as a whole, fairly well correlated $\left(r^{2}=0.58\right)$. This in itself suggests common emission sources, since, as noted previously, the photochemical routes to formation and destruction of the two species are very different in the atmosphere. The colour coding in Fig. 8, with respect to date and time, shows that the gradient of the correlation was rather different in Period $1\left(0.22 ; r^{2}=0.52\right)$ compared to later in the campaign $\left(0.33 ; r^{2}=0.57\right)$, where biomass-burning influence was significant (lines of best fit not shown). The fact that these two gradients were different, and the extent of correlation in Period $1\left(r^{2}=0.52\right)$ shows that the likely common sources of the two compounds were not simply biomass-burning sources. The analogous correlations from the MATCH data showed similar trends over the campaign as a whole (gradient $0.39 ; r^{2}=0.52$ ) and post-Period 1 (gradient $\left.0.38 ; r^{2}=0.58\right)$. However, in Period 1 the correlation between modelled acetone and methanol was very low (gradient $0.09 ; r^{2}=0.07$ ). This result suggests again that the emissions of both species, from common sources other than 
biomass burning, were greatly underestimated in the model. Again it must be noted, however, that acetone may have been predominantly a secondary photochemical product of compounds co-emitted with methanol.

Despite the good correlation observed between methanol and acetone during MINOS, the relationships between the two species and $\mathrm{CO}$ were somewhat different. Over the whole campaign, the extent of CO-acetone correlation $\left(r^{2}=\right.$ $0.39)$ was similar to that between methanol and CO $\left(r^{2}=\right.$ 0.36). However, this result conceals the fact that the level of correlation of the two species with $\mathrm{CO}$ in Period 1 was different to that found later in the campaign. In Period 1, methanol was better correlated with $\mathrm{CO}\left(r^{2}=0.43\right)$ than was acetone $\left(r^{2}=0.24\right)$. For acetone, the quite poor correlation between acetone and $\mathrm{CO}$ in the boundary layer described here may indicate that biogenic sources of acetone dominated during Period 1, since, where anthropogenic emissions are important, a high correlation is invariably observed (cf. de Reus et al., 2003). Since biomass-burning influence was low at this time, the relatively high correlation between methanol and $\mathrm{CO}$ can only be rationalized by one or more of three explanations: first, a significant anthropogenic source of methanol in Eastern Europe; second, biogenic emissions of methanol and reactive organic species such as isoprene, followed by secondary photochemical production of $\mathrm{CO}$; or third, concomitant photochemical production of $\mathrm{CO}$ and methanol from the oxidation of methane under relatively low- $\mathrm{NO}_{\mathrm{x}}$ conditions via the self-reaction of methylperoxy radicals:

$$
\mathrm{CH}_{3} \mathrm{O}_{2}+\mathrm{CH}_{3} \mathrm{O}_{2} \rightarrow \mathrm{CH}_{2} \mathrm{O}+\mathrm{CH}_{3} \mathrm{OH}+\mathrm{O}_{2} \text {. }
$$

The lack of good correlation between $\mathrm{CO}$ and acetone suggests that the second and/or third of these explanations may be the most likely. Moreover, recent reviews of the global methanol budget (Galbally and Kirstine, 2002; Heikes et al. 2002) suggest that the global anthropogenic source of methanol may be relatively small. Galbally and Kirstine (2002) estimate a global anthropogenic source of methanol in the range $3-5 \mathrm{Tg} \mathrm{yr}^{-1}$. The total source estimate they derive is $83-260 \mathrm{Tg} \mathrm{yr}^{-1}$, which implies a maximum estimated anthropogenic contribution of ca. 6\%. Heikes et al. (2002) estimate an anthropogenic methanol source term of 5-11 $\mathrm{Tg} \mathrm{yr}^{-1}$, with a total source of 90-490 $\mathrm{Tg} \mathrm{yr}^{-1}$. These figures imply a maximum anthropogenic contribution to methanol of ca. $12 \%$. A rather higher anthropogenic contribution to methanol mixing ratios $(20 \%)$ was derived by Schade and Goldstein (2001) based on measurements made in a ponderosa pine plantation in the Sierra Nevada mountains, although the authors stress that this figure should be treated as an upper limit (Sect. 3.2, p. 3115). Even assuming that up to $20 \%$ of the methanol observed during MINOS was of anthropogenic origin, we propose that only strong biogenic emissions are realistically able to explain the high methanol mixing ratios observed during Period 1 of MINOS, where biomass-burning influence was at a minimum. The
Table 3. Fitting coefficients obtained in the multiple regression analysis performed on the acetone data in Period 1 of MINOS (29 July - 2 August 2001), where biomass-burning influence was at its minumum.

\begin{tabular}{llll}
\hline Parameter & $\begin{array}{l}\text { Fitting } \\
\text { coefficient }\end{array}$ & $\begin{array}{l}\text { Contribution in } \\
\text { nmol/mol }\end{array}$ & $\begin{array}{l}\text { Percentage } \\
\text { contribution }\end{array}$ \\
\hline Benzene & 0.455 & 0.059 & 2.1 \\
Ozone & 0.007 & 0.435 & 15.1 \\
Acetonitrile & 0.679 & 0.105 & 3.5 \\
Methanol & 0.169 & 0.564 & 19.7 \\
Constant term & 1.705 & 1.705 & 59.6 \\
\hline
\end{tabular}

correlation of methanol with benzene, a well-known anthropogenic tracer, for Period 1 gave a correlation coefficient $\left(r^{2}\right.$ value) of just 0.08 . Moreover, methanol production from methane is very slow, and only likely to occur to any appreciable extent where $\mathrm{NO}_{\mathrm{x}}$ is very low. In fact, assuming a rather high 24-h mean $\mathrm{CH}_{3} \mathrm{O}_{2}$ mixing ratio of $20 \mathrm{pmol} / \mathrm{mol}$, and that the yield of methanol from the methylperoxy selfreaction is $100 \%$, which is far from the case, we calculated a methanol production rate of just $29 \mathrm{pmol} / \mathrm{mol} / \mathrm{d}$ using the latest IUPAC recommended rate data (available at http: //www.iupac-kinetic.ch.cam.ac.uk/). This amount is clearly far too small to be a significant factor in the form of the methanol diel cycle observed during MINOS. The only other known mechanism of photochemical production of methanol in the atmosphere is the photolysis of glycolaldehyde, derived from isoprene oxidation, with an estimated yield based on isoprene of ca. 2-3\% (G. Moortgat, personal communication, 2002), and biomass burning (Christian et al., 2003, and references therein). The importance of this source in the absence of biomass burning is difficult to quantify, but this does not in itself affect the argument made here, since this process too represents a biogenic source of methanol.

The correlation coefficients ( $r^{2}$ values) in linear correlations with $\mathrm{CO}$ for all data after Period 1 (excluding the short biomass burning events seen on 15 and 17 August) were 0.48 for methanol and 0.69 for acetone. The gradient of the acetone-CO correlation also shifted, from 0.006 in Period 1 to 0.014 over the rest of the campaign (cf. de Reus et al., 2003). The extent of correlation between methanol and CO did not change greatly between the non-biomass-burning influenced air masses and the biomass-burning influenced air masses. However, given the very different conditions encountered in the two periods, this seems likely to be coincidental. The good correlation between acetone and $\mathrm{CO}$ in Period 3 was almost certainly due to both direct emission of acetone during biomass burning and rapid oxidation of other emitted compounds to generate acetone in the early life of the burning plume (Mauzerall et al., 1998; Reiner et al., 2001; Jacob et al., 2002). 


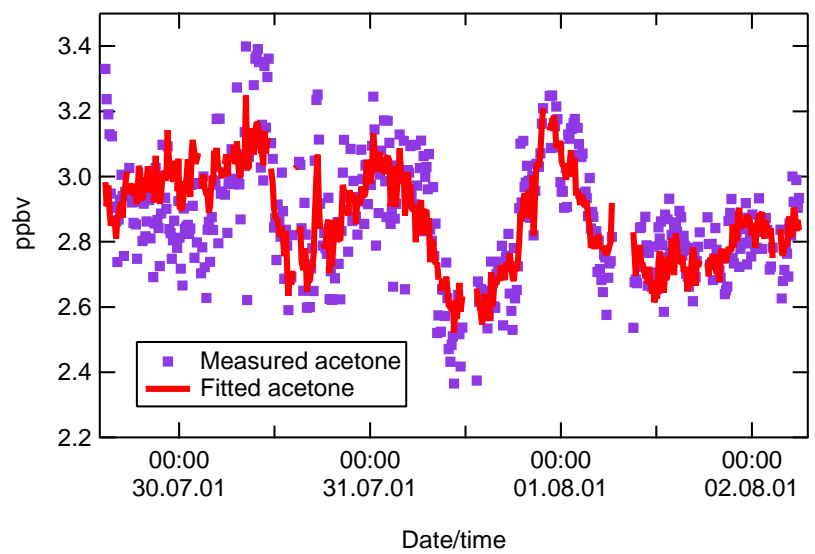

Fig. 9. Measured acetone for Period 1 compared with the results of a multivariate fitting analysis.

4.2.2 Multiple regression analysis of acetone data in Period 1

Assuming that the methanol observed during MINOS derived predominantly from biogenic emissions, it follows that this species may be used to a first approximation as a biogenic emission tracer. Consequently, a multiple regression analysis was carried out on the acetone data for Period 1, in order to examine further the sources of this compound where biomass-burning influence was at its minimum in the campaign. In this technique, the measurement series were fitted to a linear combination of other measurements, using an expression of the form:

Fit $($ Acetone $)=a+b^{*}\left(\right.$ parameter $\left.x_{1}\right)+\mathrm{c}^{*}\left(\right.$ parameter $\left.x_{2}\right)+\ldots$

where the fitting parameter a represents the background mixing ratio of acetone. The independent measurement series were chosen to represent different possible acetone sources, namely benzene for anthropogenic emission, ozone for photochemical production, acetonitrile for biomass burning emission, and methanol for biogenic emission. In this analysis, no attempt was made to define and substract background mixing ratios for the longer-lived tracers prior to the fitting procedure, because of the paucity of measurements available in this region. Tests showed that subtraction of constant values from individual tracers made no difference to the fit achieved, but merely served to raise the value of the constant, background term in the resulting analysis. The fit obtained is plotted in Fig. 9, while the chi-squared $\left(\chi^{2}\right)$ statistic, used to gauge the goodness of fit for the parameterisation, was 6.8 (where a value of 1 indicates a perfect fit). Figure 9 shows that the trends in the measurements are well captured in the fit, although the highs and lows are somewhat flattened out. The fitting coefficients obtained in this procedure are given in Table 3, together with the mean calculated contributions to the mixing ratios of acetone. These values were obtained by multiplying the coefficient for each variable by the average mixing ratio of each variable. Also given in the table are the equivalent percentage contributions by parameter, to give a clearer impression of the relative importance of the different parameters. The gradient of the line of best fit between the measurements and fitted data was 1.0, with intercept 0.0. Table 3 shows that the contributions of direct anthropogenic and biomass-burning emissions of acetone were very small (ca. 2 and $4 \%$, respectively). The use of methanol as a tracer for direct biogenic emissions suggests that $20 \%$ of the acetone observed in Period 1 of MINOS derived from this source. It is worth noting that even if we assume that $20 \%$ of the methanol observed was actually of anthropogenic origin, the results presented in Table 3 are little affected. $20 \%$ of $20 \%$ implies an extra $4 \%$ of anthropogenic acetone, making $6 \%$ in total - still a very small figure. The $15 \%$ contribution from the ozone term represents secondary photochemical production of acetone, and was probably also predominantly biogenic in origin, based on the lack of good correlation between acetone and CO, noted previously. This suggests a total biogenic contribution to the acetone mixing ratios of $35 \%$. By far the highest contribution to the observed mixing ratios was the constant term, which may be interpreted as the regional background mixing ratio of acetone $(1.7 \mathrm{nmol} / \mathrm{mol})$, and demonstrates that Finokalia is a reasonably remote measurement station. These results may be compared with those of Goldstein and Schade (2000), who derived the following contributions to acetone mixing ratios in the Sierra Nevada mountains, California, USA: anthropogenic $14 \%$ (of which $1 \%$ primary, $99 \%$ secondary), biogenic $45 \%$ (of which $35 \%$ primary, $65 \%$ secondary), $41 \%$ regional background, calculated to be $1.4 \mathrm{nmol} / \mathrm{mol}$. Both studies suggest that biogenic sources of acetone are considerably more important than anthropogenic sources, as proposed in the global budget estimates of acetone presented by Singh et al. (2000) and Jacob et al. (2002).

\section{Summary and conclusions}

In this paper we have focussed on the sources of methanol and acetone measured during the MINOS campaign in Crete, July-August 2001, particularly for Period 1 of the campaign, where the acetonitrile measurements indicated that biomassburning influence - of importance through most of the campaign - was relatively low. The air masses in this period may therefore represent typical Eastern European boundary-layer out-flow into the Mediterranean in the summer, with the following mean mixing ratios: methanol $3.3 \mathrm{nmol} / \mathrm{mol}$; acetone $2.9 \mathrm{nmol} / \mathrm{mol}$, benzene $130 \mathrm{pmol} / \mathrm{mol}, \mathrm{CO} 167 \mathrm{nmol} / \mathrm{mol}$, ozone $62 \mathrm{nmol} / \mathrm{mol}$. The mean acetone:CO, methanol:CO and acetonitrile: $\mathrm{CO}$ ratios in this period were $0.017,0.020$ and 0.0009 .

Diel cycles observed during MINOS were mainly as a result of advection to the site and/or vertical mixing, with 
evidence of photochemical production only seen in the cases of ozone (possibly in both periods) and acetone in Period 3.

A comparison of the acetone and methanol measurements with the results of the MATCH-MPIC model showed that the model reproduced quite well the larger-scale trends of both compounds. However, both species were underestimated by a factor of four on average over the whole campaign. In addition, the model:measurement ratio for both compounds was rather variable over the campaign as a whole, suggesting weaknesses in the distribution of emissions in the model. These observations in turn suggested that the relatively high mixing ratios of methanol measured during MINOS arose largely from direct emissions. Recent reviews of the global methanol budget by Galbally and Kirstine (2002) and Heikes et al. (2002) suggest that the anthropogenic contribution to the global source strength of this species is relatively small. Since the photochemical production route of methanol is rather slow, only high biogenic emissions are realistically able to explain the high methanol mixing ratios observed during MINOS.

Assuming that methanol was predominantly biogenically emitted, we used methanol as a biogenic tracer in a multivariate analysis of the acetone measurements in Period 1. The calculated contribution of direct anthropogenic emissions of acetone was found to be very small (up to 6\%). A total of $35 \%$ biogenic contribution to the observed acetone mixing ratios was obtained, assuming that the secondary photochemical production of acetone also ultimately derived from biogenic sources, while the remainder was a constant background term, representing a regional background acetone level of $1.7 \mathrm{nmol} / \mathrm{mol}$. These results imply that the missing methanol and acetone sources apparent in the MATCHMPIC model are, at least to a large extent, biogenic emissions, and also that biogenic sources of acetone are considerably more important than anthropogenic sources, as suggested in the global budget estimates of acetone presented by Singh et al. (2000) and Jacob et al. (2002).

Acknowledgement. The authors would like to acknowledge the BADC trajectory service for the back-trajectories used in this paper. Thanks to M. de Reus for her sterling work in organising the MPI side of the MINOS campaign, and to D. Scharffe for getting our container up and running. GS would like to thank L. Lange, $\mathrm{X}$. $\mathrm{Xu}$ and $\mathrm{A}$. Römpp for their help and encouragement during the experiment, and J. Sciare, F. Slemr and J. Crowley for useful comments on this work.

\section{References}

Berresheim, H., Plass-Dülmer, C., Elste, T., and Mihalopoulos, N.: $\mathrm{OH}$ in the coastal boundary layer of Crete during MINOS: measurements and relationship with ozone photolysis, Atmos. Chem. \& Phys. Discuss., 3, 1183-1212, 2003.

Caplan, P. and Pan, H. L.: Changes to the 1999 NCEP Operational MRF Model Analysis/Forecast System, National Centers for Environmental Prediction, Silver Spring, NCEP Pub. No. 452,2000

Christian, T. J., Kleiss, B., Yokelson, R.J ., et al.: Comprehensive laboratory measurements of biomass-burning emissions I. The emissions from Indonesian, African, and other fuels, submitted to J. Geophys. Res., 2003.

de Reus, M., Fischer, H., Arnold, F., de Gouw, J., Warneke, C., and Williams, J.: On the relationship between acetone and carbon monoxide in air masses of different origin, Atmos. Chem. \& Phys. Discuss., 3, 1017-1049, 2003.

Galbally, I. E. and Kirstine, W.: The production of methanol by flowering plants and the global cycle of methanol, J. Atmos. Chem., 43, 195-229, 2002.

Goldstein, A. H. and Schade, G. W.: Quantifying biogenic and anthropogenic contributions to acetone mixing ratios in a rural environment, Atmos. Environ., 34, 4997-5006, 2000.

Gros, V., Williams, J., van Ardenne, J., Salisbury, G., Hofmann, R., Lawrence, M., von Kuhlmann, R., Lelieveld, J., Krol, M. Berresheim, H., Lobert, J. M., and Atlas, E.: Origin of anthropogenic hydrocarbons and halocarbons measured in the summertime European outflow (on Crete in 2001), Atmos. Chem. \& Phys. Discuss., 3, 1893-1923, 2003.

Guenther, A., Hewitt, C. N., Erickson, D., Fall, R., et al.: A global model of natural volatile organic-compound emissions, J. Geophys. Res., 100, 8873-8892, 1995.

Hansel, A., Jordan, A., Holzinger, R., Prazeller, P., Vogel, W., and Lindinger, W.: Proton transfer mass spectrometry: on-line trace gas analysis at ppb level, Int. J. Mass Spectrom., 150, 609-619, 1995.

Harrison, D., Hunter, M. C., Lewis, A. C., Seakins, P. W., Bonsang, B., Gros, V., Kanakidou, M., Touaty, M., Kavouras, I., Mihalopoulos, N., Stephanou, E., Alves, C., Nunes, T., and Pio, C.: Ambient isoprene and monoterpene concentrations in a Greek fir (Abies Borisii-regis) forest: reconciliation with emissions measurements and effects on measured $\mathrm{OH}$ concentrations, Atmos. Environ., 35, 4699-4711, 2001.

Heikes, B. G., Chang, W., Pilson, M. E. Q., et al.: Atmospheric methanol budget and ocean implication, Global Biogeochem. Cyc., 4, 1133, doi:10.129/2002GB001895, 2002.

Holzinger, R., Warneke, C., Hansel, A., et al.: Biomass burning as a source of formaldehyde, acetaldehyde, methanol, acetone, acetonitrile, and hydrogen cyanide, Geophys. Res. Lett., 26, 11611164, 1999.

Holzinger, R., Kleiss, B., Donoso, L., and Sanhueza, E.: Aromatic hydrocarbons at urban, suburban, rural $\left(8^{\circ} 52^{\prime} \mathrm{N} ; 67^{\circ} 19^{\prime} \mathrm{W}\right)$ and remote sites in Venezuela, Atmos. Environ., 35, 4917-4927, 2001a.

Holzinger, R., Jordan, A., Hansel, A., and Lindinger, W.: Automobile emissions of acetonitrile: assessment of its contribution to the global source, J. Atmos. Chem., 38, 187-193, 2001 b.

Holzinger, R., Kleiss, B., Crutzen, P. J., Lobert, J. M., and Kaene, W. C.: VOC emissions from savannah fuels, manuscript in preparation, Atmos. Chem. \& Phys., to be submitted, 2003.

Jacob, D., Field, B., Yin, E., Bey, I., Li, Q., Logan, J., Yantosca, R., and Singh, H.: Atmospheric budget of acetone, J. Geophys. Res., 107, 10.1029/2001JD000694, 2002.

Kirstine, W., Galbally, I., Ye, Y., and Hooper, M.: Emissions of volatile organic compounds (primarily oxygenated species) from pasture, J. Geophys. Res., 103, 10 605-10 609, 1998. 
von Kuhlmann, R.: Photochemistry of tropospheric ozone, its precursors and the hydroxyl radical: a 3D-modeling study considering non-methane hydrocarbons, Ph.D. thesis, Johannes Gutenberg-Universität Mainz, Mainz,Germany, 2001.

von Kuhlmann, R., Lawrence, M. G., Crutzen, P. J., and Rasch, P. J.: A model for studies of tropospheric ozone and nonmethane hydrocarbons: Model description and ozone results, J. Geophys. Res., 108, 4294, doi:10.1029/2002JD002893, 2003a.

von Kuhlmann, R., Lawrence, M. G., Crutzen, P. J., and Rasch, P. J.: A model for studies of tropospheric ozone and nonmethane hydrocarbons: Model evaluation of ozone related species, submitted to J. Geophys. Res., doi:10.1029/2002JD003348, 2003 b.

Lange, L., Williams, J., Lawrence, M., von Kuhlmann, R., Vrekoussis, M., Economou, C., Mihalopoulos, N., and Lelieveld, J., The budget of reactive nitrogen species at a ground-based station on Crete during the MINOS 2001 campaign, Atmos. Chem. \& Phys., submitted.

Lawrence, M. G., Crutzen, P. J., Rasch, P. J., Eaton, B. E., and Mahowald, N. M.: A model for studies of tropospheric photochemistry: Description, global distributions, and evaluation, J. Geophys. Res., 104, 26 245-26 277, 1999.

Lelieveld, J., Berresheim, H., Borrmann, S., et al.: Global air pollution crossroads over the Mediterranean, Science, 298, 794-799, 2002.

Lindinger, W., Hansel, A., and Jordan, A.: On-line monitoring of volatile organic compounds at pptv levels by means of ProtonTransfer-Reaction Mass Spectrometry (PTR-MS): medical applications, food control and environmental research, Int. J. Mass Spectrom., 173, 191-241, 1998.

Lobert, J. M., Scharffe, D. H., Hao, W. M., and Crutzen, P. J.: Importance of biomass burning in the atmospheric budget of nitrogen-containing gases, Nature, 346, 552-554, 1990.

Mahowald, N. M., Rasch, P. J., Eaton, B. E., Whittlestone, S., and Prinn, R. G.: Transport of ${ }^{222}$ radon to the remote troposphere using the Model of Atmospheric Transport and Chemistry and assimilated winds from ECMWF and the National Center for Environmental Prediction/NCAR, J. Geophys. Res., 102, 28 13928 152, 1997a.

Mahowald, N. M., Prinn, R., and Rasch, P. J.: Deducing $\mathrm{CCl}_{3} \mathrm{~F}$ emissions using an inverse method and chemical transport models with assimilated winds, J. Geophys. Res., 102, 28153 28 168, 1997b.

Mauzerall, D. L., Logan, J. A., Jacob, D. J, Anderson, B. E., et al.: Photochemistry in biomass burning plumes and implications for tropospheric ozone over the tropical South Atlantic, J. Geophys. Res., 103, 8401-8423, 1998.

McKenna, D., Hord, C., and Kent, J.: Hydroxyl radical concentrations and Kuwait oil fire emission rates for March 1991, J. Geophys. Res., 100, 26 005-26 025, 1995.

Mihalopoulos, N., Stephanou, E., Pilitsidis, S., Kanakidou, M., and Bousquet, P.: Atmospheric aerosol composition above the Eastern Mediterranean region, Tellus, 49B, 314-326, 1997.

Moschonas, N. and Glavas, S.: Non-methane hydrocarbons at a high-altitude rural site in the Mediterranean (Greece), Atmos. Environ., 34, 973-984, 2000.

Pöschl, U., von Kuhlmann, R., Poisson, N., and Crutzen, P. J.: Development and intercomparison of condensed isoprene oxidation mechanisms for global atmospheric modeling, J. Atmos. Chem., $37,29-52,2000$.
Rasch, P. J., Mahowald, N. M., and Eaton, B. E.: Representations of transport, convection and the hydrologic cycle in chemical transport models: implications for the modeling of short lived and soluble species, J. Geophys. Res., 102, 28 127-28 138, 1997.

Reiner, T., Sprung, D., Jost, C., Gabriel, R., Mayol-Bracero, O. L., Andreae, M. O., Campos, T. L., and Shetter, R. E.: Chemical characterization of pollution layers over the tropical Indian Ocean: signatures of emissions from biomass and fossil fuel burning, J. Geophys. Res., 106, 28 497-28 510, 2001.

Roberts, J., Felsenfeld, F., Liu, S., Bollinger, M., Hahn, C., Albritton, D., and Sievers, R.: Measurements of aromatic hydrocarbon ratios and $\mathrm{NO}_{\mathrm{x}}$ concentrations in the rural troposphere: observations of airmass photochemical aging and $\mathrm{NO}_{\mathrm{x}}$ removal, Atmos. Environ., 18, 2421-2432, 1984.

Sanz, M. J. and Millán, M. M.: The dynamics of aged air masses and ozone in the Western Mediterranean: relevance to forest ecosystems, Chemosphere, 36, 1089-1094, 1998.

Schade, G. W and Goldstein, A. H.: Fluxes of oxygenated volatile organic compounds from a ponderosa pine plantation, J. Geophys. Res., 106, 3111-3123, 2001.

Schneider, J., Borrmann, S., Wollny, A., Blsner, M., Mihalopoulos, N., Bardouki, H., and Sciare, J.: Ground-based particle measurements during MINOS (Crete, August 2001): Size distribution and inorganic chemical composition, Atmos. Chem. \& Phys., submitted, 2003.

Singh, H. B., Kanakidou, M., Crutzen, P. J., and Jacob, D. J.: High concentrations and photochemical fate of oxygenated hydrocarbons in the free troposphere, Nature, 78, 50-54, 1995.

Singh, H., Chen, Y., Tabazadeh, A., et al.: Distribution and fate of selected oxygenated organic species in the troposphere and lower stratosphere over the Atlantic, J. Geophys. Res., 103, 37953805, 2000.

Tsigaridis, K. and Kanakidou, M.: Importance of volatile organic compound photochemistry over a forested area in central Greece, Atmos. Environ., 36, 3137-3146, 2002.

Warneke, C., van der Veen, C., Luxembourg, S., de Gouw, J. A., and Kok, A.: Measurements of benzene and toluene in ambient air using proton-transfer-reaction mass spectrometry: calibration, humidity dependence, and field intercomparison, Int. J. Mass Spectrom., 207, 167-182, 2001.

Wennberg, P. O., Hanisco, T. F., Jaeglé, L., et al.: Hydrogen radicals, nitrogen radicals, and the production of $\mathrm{O}_{3}$ in the upper troposphere, Science, 279, 49-53, 1998.

Williams, J., Pöschl, U., Crutzen, P. J., Hansl, A., Holzinger, R., Warneke, C., Lindinger, W., and Lelieveld, J.: An atmospheric chemistry interpretation of mass scans obtained from a proton transfer mass spectrometer flown over the tropical rainforest of Surinam, J. Atmos. Chem., 38, 133-166, 2001.

Xu, X., Williams, J., van Stee, L., Beens, J., Adahchour, M., Vreuls, R., and Lelieveld, J.: Comprehensive two-dimensional gas chromatography (GCxGC) measurements of volatile organic compounds in the atmosphere, Atmos. Chem. \& Phys. Discuss., 3, 1139-1181, 2003a.

Xu, X., Williams, J., Plass-Dülmer, C., Berresheim, H., Salisbury, G., Lange, L., and Lelieveld, J.: GC x GC measurements of C7$\mathrm{C} 11$ aromatic and n-alkane hydrocarbons on Crete, in air from Eastern Europe during the MINOS campaign, Atmos. Chem. \& Phys. Discuss., 3, 1477-1513, 2003 b. 